\title{
Food and Shelter Problems for Winter Birds
}

During a severe winter, such as we are having on the prairies this year, there are interesting observations to be made on the various means by which our native birds find food and shelter. A number of readers have written to the Blue Jay about the birds wintering in their locality, and we notice in Regina that the continued cold weather seems to have brought into the shelter of the park at the Legislative Buildings an unusual number of winter visitants.

In the Legislative Grounds a flock of White-winged Crossbills and a few Red Crossbills have been feeding all winter on the plentiful crop of spruce cones. Whenever these birds are feeding in a tree, their presence is soon obvious from the shower of cones falling to the ground. A timely item on the wasteful feeding of White-Winged Crossbills came to our notice in the September 1955 issue of The Wilson Bulletin. In a note from $P$. R. Hofslund, William $H$. Marshall, and Gerald Robinson, of the University of Minnesota Biological Station, Lake Itasca, Minnesota, an adult male and three presumably immature White-winged Crossbills (Loxia leucoptera) were reported feeding on the cones of White Spruce (Picea glauca). The method of feeding was peculiarly wasteful in that the cones were clipped off from the cluster, held on a branch by one foot, and then a few scales were torn off and the cone was dropped. Marshall and Robinson timed the procedure for 30 minutes. Fifty-nine cones were clipped off and dropped during the half hour at a rate of 20,20 , and 19 per 10-minute period. After the birds moved on, the cones under the trees where these birds were feeding were collected and given to Hofslund for examination. From a total of 619 cones, few had more than four or five scales torn off.

Mrs. Hubbard (Grenfell) reports that Pine Grosbeaks which have visited their farm several times this winter go to the orchard for frozen crabapples (as do our Bohemian Waxwings). In the Legislative Park in Regina we have more commonly observed them eating the winged seeds of ash and maple, and occa- sionally the buds of willows. The economic status of these birds is probably as nearly neutral as that of any species, but their pleasing whistle and the handsome flush of rose of the mature male's colouring make these visitors from the northern forests peculiarly welcome.

The attractiveness of cover in severe weather may account for the fact that Sharp-tailed Grouse are being seen this winter in the Legislative Grounds. Mrs. Steve Mann (Piapot) reports seeing flocks of thirty or forty Sharp-tails that have moved from the fields to feed along the open highway.

Under severe weather conditions, birds find shelter in unusual spots. Boswell Belcher reports that, following the December blizzard, a Golden Eagle flew up out of the farm shelter belt at Dilke. He also writes about the Slate-coloured Juncos that shelter on the farm in spring and fall migration.

"One cold stormy evening" last spring as Dad and I were driving around the stackyard, which is inside the yard shelterbelt, to get feed for the cattle dozens of juncos flew out of the cracks between the bales where they had sought shelter for the night. Again in late October as we went by our bale stack in the field to start hauling bales in the morning we found our friends once again, and concluded that these birds must approve of modern haying methods!" These examples show the resourcefulness of birds in utilizing existing shelter.

To some extent, of course, food and shelter can be provided for winter birds. Many types of feeding trays are in use, from the most elaborate to such simple ones as the flat salmon tins hung in the caragana bush on the Beaver Creek Game Farm to hold suet for friendly Chickadees. Mrs. Hubbard, Grenfell, has regular visitors this year to the suet she puts out in soup bones three Hairy Woodpeckers, three Chickadees, and a Canada Jay. She notes by comparison that because of the mild weather last winter, suet from last spring was still hanging in the honeysuckle in September. Joyce Gunn at Spirit Lake makes a (Continued on page 21) 


\section{FOOD AND SHELTER}

(Continued from page 17)

similar observation: "We have more small birds feeding on the windowsill tray this winter than we usually have. Besides the usual Chickadees and Woodpeckers, this winter we have three White-breasted Nuthatches feeding here."

When disaster strikes, as in an unseasonable storm, special measures are often effective. During the snowstorm and freezing temperatures that followed it in early. May, 1954, Mrs. W. E. Cooper of Gravelbourg, rescued waders that would not eat the grain thrown out for other birds, by breaking the ice and putting a gallon of oat chop into the mud from which the water birds would dig it out and eat it. Following a heavy, wet snow late in April, 1955 the F. A. Wilsons at Struan ploughed the snow to maintain bare patches of ground where they could feed chop and oatmeal to Juncos, Tree Sparrows, Song Sparrows, Whitecrowned Sparrows and Robins.

Some farms are much better suited than others to attracting and sheltering birds. Mrs. W. E. Cooper describes the features of their farm at Gravelbourg that make it a wildlife haven - a tree belt of several hundred evergreens which is a home and nesting place for hundreds of birds, a flower garden which Mrs. Cooper was delighted to have visited by a Ruby-throated Hummingbird, and a large stock dam and a dug-out with trees all around it that supplies water for them all.

This is the time of year to consider planting trees and shrubs that provide shelter for winter birds. A bulletin from the Experimental Farm at Morden, Manitoba (November 5,
1955) recommends the following woody plants of use to winter birds; hawthorn, roses, Manchurian crabapple, Cherry prinsepia, silverberry, Russian olive, buffaloberry, snowberry, pembina or highbush cranberry, nannyberry, seabuckthorn, sumac, juniper, hazel, oak, barberry, cotoneaster, Russian sloe, buckthorn, arrowwood, basswood, hackberry, Amur lilac, mountain ash, Amur maple and wild grape. The bulletin also lists the following herbaceous plants of use: sweet clover, corn, sunflowers, sorghum and alfalfa. The Morden Experimental Farm contributes seed and some plants to Government game farms and Game and Fish Associations which are extending plantings to provide food and shelter for grouse, partridge and pheasants.

To the Morden list, the Extension Gardeners' Guild of the University of Saskatchewan adds the following trees and shrubs: chokecherry, pincherry, Mongolian cherry, Rocky Mountain juniper, Scotch and Lodgepole pine. Two species of mountain ash are listed as suitable - the Showy and the American, and two honeysuckles - the Tartarian and Amur. Almost all of these plants are available from western nurseries, and they can also be grown from seed although in some cases the seeds germinate slowly. D. R. Robinson of the Extension Department, University of Saskatchewan, would be glad to hear from anyone interested in this subject.

A useful little bulletin, Attracting Birds, may be obtained for 15 cents from the U.S. Fish and Wildlife Service. Write the Superintendent of Documents, U.S. Government Printing Office, Washington 25, D.C.

\section{COVER PICTURES}

The two Blue Jays on the front cover were rescued, fed and finally released by $\mathrm{Mr}$. and Mrs. L. Keresztes in New York. A series of 14 beautiful photographs are shown in the October, 1955, Nature Magazine. Mr. and Mrs. Keresztes sent us a series of 11 fine kodachrome transparencies which were enjoyed by all who attended our Annual Meeting last October 29. The front cover shows Lefty and Tweedy investigating some of the strange environment of a city apartment. I hope they still return from the woods and parks of New York to bring nature news to their friends the Keresztes. Three Blue Jays were reported in the Christmas Bird Count from Skull Creek. Mr. S. A. Mann notes that this is the first sight record in the area since 1920 , when one was seen.

The back cover features the Canada Jay. Mr. Doug Gilroy (in his hundredth article in the series Prairie Wildlife in the Western Producer, January 19, 1956) mentions the rather unusual southward movement of these birds this winter. We have a few additional reports: $P$. Laurence Beckie reports (November 24, 1955) seeing the Canada Jay at Bladworth on the following dates: October 26, November 5, November 6, November 19) (a pair feeding near the barn). He comments that he has not seen a. Canada Jay for some nine years. Mrs. John Hubbard, Grenfell, reports the first Canada Jays she has ever seen. Mr. Hubbard says there ased to be Jays when the incal farmers operated a. beef ring. 